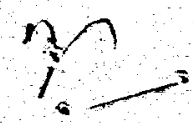

\title{
MEXICAN-AMERICAN COOPERATIVE PROGRAM AT THE CERRO PRIETO GEOTHERMAL FIELD
}

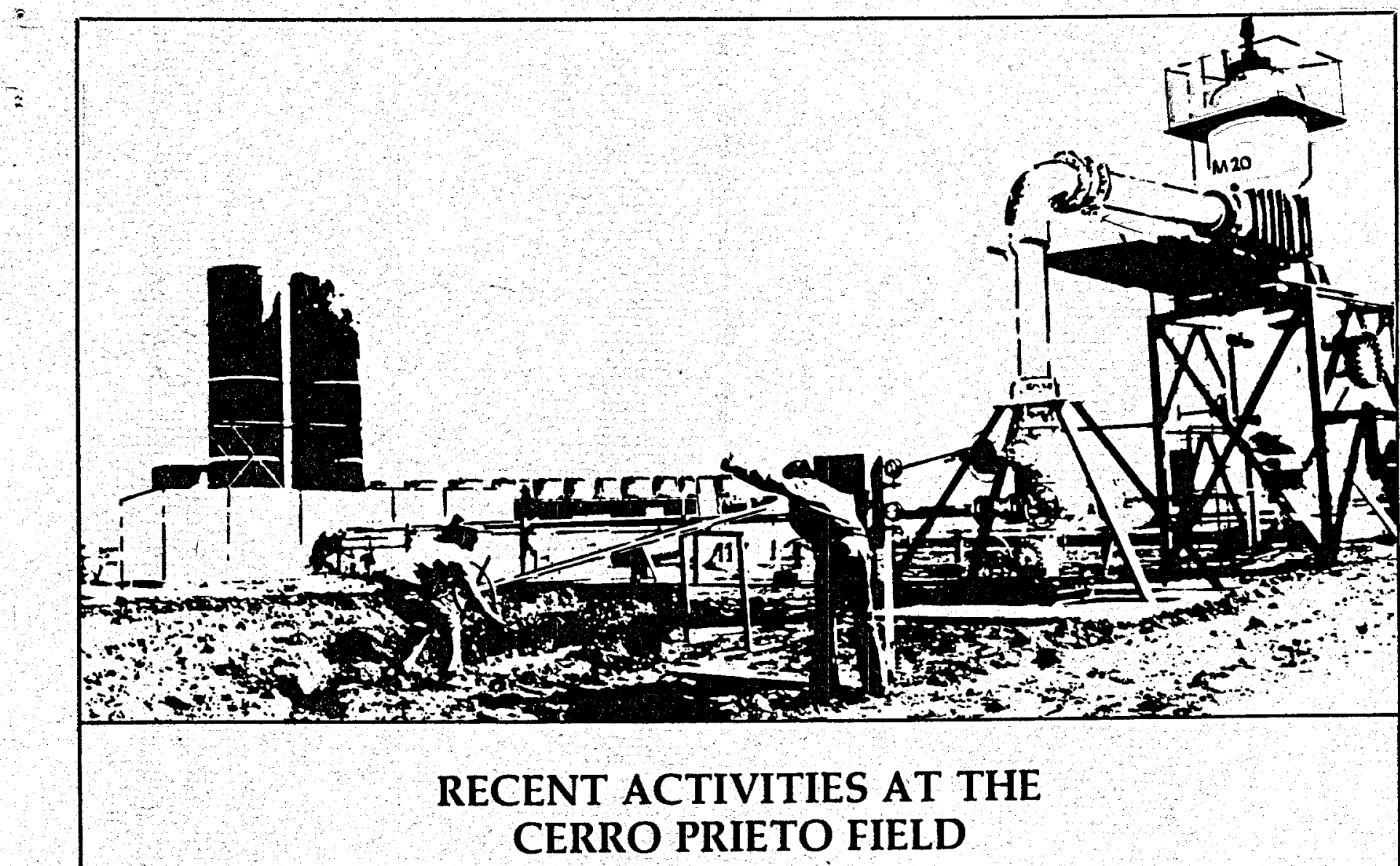

Alonso E., H., Domínguez A., B., Lippmann, M. J., Man̄on M., A., Schroeder, R. C., and Witherspoon, P. A.

December 1978

A Joint Project of

COMISION FEDERAL DE ELECTRICIDAD

(1)

LBL-8538
RIETO-02 


\section{DISCLAIMER}

This report was prepared as an account of work sponsored by an agency of the United States Government. Neither the United States Government nor any agency Thereof, nor any of their employees, makes any warranty, express or implied, or assumes any legal liability or responsibility for the accuracy, completeness, or usefulness of any information, apparatus, product, or process disclosed, or represents that its use would not infringe privately owned rights. Reference herein to any specific commercial product, process, or service by trade name, trademark, manufacturer, or otherwise does not necessarily constitute or imply its endorsement, recommendation, or favoring by the United States Government or any agency thereof. The views and opinions of authors expressed herein do not necessarily state or reflect those of the United States Government or any agency thereof. 


\section{DISCLAIMER}

Portions of this document may be illegible in electronic image products. Images are produced from the best available original document. 
LEGAL NOTICE

This report was prepared as an account of work sponsored by the United States Government. Neither the United States nor the United States Department of Energy, nor any of their employees, nor any of their contractors, subcontractors, or their employees, makes any warranty, express or implied, or assumes any legal liability or responsibility for the accuracy, completeness or usefulness of any information, apparatus, product or process disclosed, or represents that its use would not infringe privately owned rights. 


\author{
Alonso E., H. ${ }^{1}$, Domínguez A., B. ${ }^{1}$, Lippmann, M.J. ${ }^{2}$, \\ Hañon M., A. ${ }^{2}$, schroeder, R.C. ${ }^{2}$, and Witherspoon, P.A. 2 \\ ${ }^{1}$ Comisión Federal de Electricidad \\ Coordinadora Ejecutiva de Cerro Prieto \\ Mexical1; Baja Callfornia, Mexico \\ 2awrence Berkeley Laboratory
Earth Sclences Division
Berkeley, California 94720
}

\title{
INTRODUCTION
}

The purpose of this paper is to describe some of the latest activities of Interest to reservoir engineers at the Cerro Prieto geothermal field. Special emphasts is given to the wells drilled in 1978 for exploration purposes and to provide steam to the existing and future power plants. The present power output is $75 \mathrm{M}$. Two addittonal $37.5 \mathrm{MW}$ units are scheduled to go on 1ine in March and Yay 1979, while the total generating capecity at Cerro Prieto will reach about 400MW in 1985, Additional information is avallable in a number of papers in References 1 and 2:

\section{NEW WELLS (FIgure 1)}

At the present time (December 1978), there are six drilling rigs active, four for new wells and two to repair old ones. Because of generally different reservolr conditions and depths, the Cerro Prieto fleld can be divided into three blocks: Block I, presentiy the maIn producing area, centered around $M-5$; Block II, south of Iine which approximately passes through wells M-35 and M-46; and Block III, NE of the rallroad track which roughly colncides, with the trace of the Cerro.Prieto fault. drilled.

In 1978 twelve wells have been completed and three are presently being

Production Wel1s: $M-43, M-102, M-103, M-104, M-114, M-130, M-181, T-366$ Exploration Wells: M-93, M-94, M-96, S-262

Wells Being Drilled: M-107, M-123, M-150

Depth: The average depth of these wells $1 \mathrm{~s} 2000 \mathrm{~m}$; the deepest are $T-366(2980 \mathrm{~m})$ and $M-96(2728 \mathrm{~m})$. The new production wells have reached the hot water reservolr (s) between: 1500 and $1700 \mathrm{~m}$ (Block I, We11s M-43,M-114, M-130), 1453 and $1610 \mathrm{~m}$ (Block II, Well M-181), and 1800 and $2000 \mathrm{~m}$ (Block III, Wells $M-102, M-103, M-1 C 4$ ).

Lithologic and Temperature Characteristics: In Block I the downhole temperatures measured were: $294^{\circ} \mathrm{C}(M-130), 271^{\circ} \mathrm{C}(M-114), 265^{\circ} \mathrm{C}(M-43)$, which are only moderate for this block. While in Block II, $287^{\circ} \mathrm{C}$ was measured at the bottom of $M-181$.

In Block III, the downhole temperatures in $M-102$ and $M-104$ are about $345^{\circ} \mathrm{C}$, similar to $M-53$. To the $N W$, in $M-94$, it only reached $208^{\circ} \mathrm{C}$. The 11thologic column and structural conditions found In M-53, drilled in 1974, are generally repented in wells $M-102, M-103$ and $M-104$. Nevertheless, towards the $S E$ the 
permeable hot zone deepens quite appreclably. It was found between 2400 and $2560 \mathrm{~m}$ in $M-93$, and between 2427 and $2922 \mathrm{~m}$ in $T-366$. In these two wells the characteristic of the productive intervals is quite different. In M-93 high permeability zones were indicated by large lost circulations. On the other hand, In T-366 these losses were minimal, and visual inspection of the recovered cores Indicate low permeabilities. (A relatively long perforated interval was installed in this well.) The temperatures measured in the
drilling muds at rest in the well were $221 \mathrm{C}(\mathrm{M}-93)$ and $230^{\circ} \mathrm{C}(\mathrm{T}-366)$. These values suggest that after cleaning the wells and a heating up perlod, the temperatures will reach at least $340^{\circ} \mathrm{C}$. This seems to Indicate that Block III may have production potential, independent of an apparent decrease $1 n$ permeability and Increase of depth towards the SE. This area, which already has seven completed wells, will supply steam to the Cerro Prieto II plant (additional 110MW by 1983 and $220 \mathrm{MW}$ by 1985)

Exploration well $\mathrm{M}-96$, NW of the main production area, reached bsgement at about $2713 \mathrm{~m}$. The maximum temperature $\left(108^{\circ} \mathrm{C}\right)$ was reached at $1977 \mathrm{~m}$; $97^{\circ} \mathrm{C}$ was measured at $300 \mathrm{~m}$ indicating a shallow hot aquifer. South of the field another exploratory we11, S-262, penetrated bàsement at $1470 \mathrm{~m}$. There, the highest temperature was measured at the bottom of the hole $\left(100^{\circ} \mathrm{C}\right)$.

Casings (Figures 2 and 3): In most of the wells built in 1978 a 7-5/8" $\mathrm{K}-55,45.3 \mathrm{lb} / \mathrm{ft}$. casing with Hydrill Super EU thread was used. When required, as in $M-102$ and $M-94, a 5^{\prime \prime} \emptyset, R-55,23 \mathrm{lb} / \mathrm{ft}$. liner with Super EU thread was Installed. Recently it was decided to change the diameter of the production casing to 9-5/8" to Increase steam production and because it is easter to obtain commerctally. In $M-103$ and $T-366$ a $9-5 / 8 " \emptyset, N-80,471 b / f t$. production casing with Buttress thread and $7 " 0, N-80,29 \mathrm{lb} / \mathrm{ft}$. hanging and cemented liner with Hydrill Super EU thread were installed. With the new grade of casing larger mechanical capacity has been sought to better withstand the tension and compression stresses which have created many problems at Cerro Prieto. Nevertheless, one will have to wait to find out the corrosive effect of the geothermal fluids on this type of casing.

\section{DRILLING PROBLEMS}

Three main problems during the drilling of these wells have been encountered: a) lost circulation during drilling and cementing operations, b) fishing problems, and c) cave-ins and stuck tools.

Last Circulation: During drilling and cementing, this is the most important problem. In some cases, circulation losses could be controlled. In other cases, like in $\mathrm{M}-93$, almost $100 \mathrm{~m}$ were drilled with complete loss of circulation In order to clearly penetrate into the producing layer and get good production. This may result in stuck pipes and in cementing problems. With this procedure, the probability of losing cement slurry into the formation is increased. This is a severe problem because the production casing could fail when the well is heated up. In some cases, like in $M-93, M-123$ and $M-150$, in addition to losses near the production zones, lost circulation has occurred in the upper $1000 \mathrm{~m}$, while cementing the $11-3 / 4^{\prime \prime} \emptyset$ or $13-3 / 8^{\prime \prime} \emptyset$ surface casing. This situation is very serious because the safety of the anchor and seals which prevent upward flows depend heavily on a good cement job. This problem was only encountered In Block III, and is related to the high permeability of its sandy layers. 
Fishing Problems: These problems are closely related to c1rculation losses since they create conditions which may end with tools getting stuck in the borehole. Then, if the tools fall mechanically a fishing problem results. Some fishing operations were successful, but In $M-94$ and $M-103$ they falled.

In M-94 it was decided to hang a $5^{\prime \prime} \emptyset$ production casing in the upper part of the producing zone which remained open. Pipes which could not be fished out were left in the hole from 2328 to $2601 \mathrm{~m}$. Th1s lower part of the well showed high temperatures but low permeability. Another interval of high temperature, presently covered by the casing, was detected at $1600 \mathrm{~m}$, it showed a maximum of $214^{\circ} \mathrm{C}$.

In $M-103$ because of the good thermal characteristics of the well, it was decided to slant-drill above the fish. The drilling was successful but there exists uncertainty about the behavior of the $9-5 / 8^{\prime \prime}$ production casing when the well heats up. The thermal expansion in the area of deviation, may produce collapse or fracture of the casing. This is being watched as the well begins to heat up.

Cave-Ins and Stuck Todls: Another problem is the caving of shales near the high temperature zones. This occurs when the drilling operation takes too long, because of lost circulation or other causes. Th1s is well known in the oil Industry when the drilling lasts more than 60 days. In Cerro Prieto it is complicated by the presence of fractures or possibly faults which 1ncrease the probebility of cavings. This results in stuck or caught tools.

When this situation develops, special mud conditions are used in the hole. But if this does not stop the caving, temporary plugs of cement bridging the zones affected are used to stablize the formations. This will allow the installation and cementing of casing which will definitely solve the problem.

In Blocks I and II these types of problems have not occurred or have been easily solved following the procedure described, but in Block III they have been more severe.

\section{DEVELOPMENT OF NEW WELLS}

A number of wells drilled before 1978 were developed this year. The chemical characteristics of the separated brine produced are given in Table 1.

From the 1978 wells $M-102, M-114$ and $M-130$ have been developed. Figure 4 shows the evolution of the characteristics of $M-102$ during the later part of Its development. With time and orifice-diameter changes there is a marked variation In the wellhead pressures. However, chemical indices and the "Na-K-Ca" geothermometer remain essentially constant. At Cerro Prieto when orifices (or purges) are changed, these parameters are used to detect any possible variation in the downhole source of the produced steam-brine mixture.

Total production of $\mathrm{M}-102$ was 120 tonnes $/ \mathrm{hr}$. of steam and 180 tonnes $/ \mathrm{hr}$. of brine at 13,8 bars ( $200 \mathrm{psig})$. This is a good well, and even better characteristics are expected to be found in the rest of the wells in Block III, especially in $T-366$ and $M-93$ which are only beginning to heat up. 
TABLE 1

CHARACTERISTICS OF CERRO PRIETO MELLS DEVELOPED DURING 1970

\begin{tabular}{|c|c|c|c|c|c|c|c|c|c|c|}
\hline WELL & DATE & $\begin{array}{c}\text { PERFORATED INTERVAL } \\
\text { (depth m) }\end{array}$ & $\begin{array}{l}\text { FLOW } \\
\text { CONDITIONS }\end{array}$ & $\begin{array}{l}\text { WELLHEAD } \\
\text { PRESSURE } \\
\text { bars (g) }\end{array}$ & $\mathrm{Na}$ & $\begin{array}{c}k \\
m / 1\end{array}$ & $\begin{array}{c}\mathrm{Ca} \\
\mathrm{mg} / 1\end{array}$ & $\mathrm{cl}$ & TEMP: & $\begin{array}{c}\text { ENTHALPY } \\
\mathrm{kJ} / \mathrm{kg}\end{array}$ \\
\hline$M-50$ & $11 / 24 / 78$ & $1144-1249$ & 6" cone & 14.0 & 7009 & 1859 & 337 & 12958 & 306 & 1379 \\
\hline$M-5 !$ & $2 / 8 / 78$ & $1245-1567$ & $\because 6 " 1$ orif. & 23.1 & 10600 & 3342 & 551 & 20534 & 335 & 1561 \\
\hline$M-53$ & $6 / 20 / 78$ & $1845-1996$ & $5-1 / 2^{\prime \prime}$ ortf. & 12.1 & 10396 & 3454 & 429 & 19692 & 345 & 1632 \\
\hline$M-84$ & $8 / 4 / 78$ & $1536-1691$ & $5^{\prime \prime}$ b cone & 22.1 & 10341 & 3118 & 486 & 19694 & 325 & 1494 \\
\hline$M-90$ & $2 / 20 / 78$ & $1221-1379$ & $5^{\prime \prime}$ orif. & 15.1 & 6221 & 1773 & 242 & 12242 & 320 & 1460 \\
\hline$M-91$ & $2 / 2 / 78$ & $2133-2294$ & 6" orlf. & 17.9 & 9281 & 2476 & 405 & 16757 & 318 & 1448 \\
\hline$m-101$ & $5 / 19 / 78$ & $1193-1394$ & 6" Dorlf. & 6.4 & 2703 & 423 & 3 & 4310 & 241 & 1042 \\
\hline$M-102$ & $10 / 20 / 78$ & $1793-1990$ & 61' orif. & 19.3 & 11266 & 3342 . & 481 & 21019 & 329 & 1519 \\
\hline$M-105$ & $10 / 18 / 78$ & $1480-1673$ & 6" 5 cone & 15.7 & 9793 & 2851 & 529 & 18794 & $\mathbf{3 2 0}$ & 1462 \\
\hline
\end{tabular}




\section{WELL TESTING}

Measurements of temperatures, pressures, flow-rates, and enthalpies have been made for several years at Cerro Prieto. During 1978 several well tests have been performed, and data from long-term measurements in $M-6$ and $M-10$ have been collected. Preliminary analyses of data have been made for the measurements 11sted in Table 2. The water-level data from $M-6$ is quite satisfactory, but are not considered to be reliable due to the different depths of penetration, and large differences in temperature at $M-6$ and within the producing field. When reservolr simulation is used this data will be very valuable. The well test Involving $M-101$ has been analyzed, but the values for $\mathrm{kh} / \mu$ and $\phi \mathrm{ch}$ cannot be considered to be satisfactory, since recent reservoir models suggest that two or more separate aquifers are penetrated at different depths by the five wells involved in the test. The measurements made when $M-53$ was brought on-line would have made a contribution to our knowledge of that portion of the field, but anomalous increases in water level (downhole pressure) completely obscured the M-53 production effect for several weeks. The anomalous behavior has been ascribed to a medium-scale earthquake ( 5.3 Richter) whose epicenter was about $20 \mathrm{~km}$ south of the production field. The water levels rose before the earthquake (1n spite of the drawdown), and began to decrease slowly soon after the major shock.

Several productivity tests have been made using two or more rate changes as a means of determining near-well parameters. The data for three such tests carried out during the long interference test with $M-101$ has been studied, but the multiple aquifer effects have made the parameter values difficult to determine.

Presently, there are additional analyses, simulation of well tests, and new measurements in the planning stage for 1979. Efforts will be made to determine the hydrological characteristics of the stratigraphic discontinulty between BIocks II and III.

TABLE 2

SUMHARY OF WELL TEST RESULTS

\begin{tabular}{|c|c|c|c|}
\hline $\begin{array}{l}\text { OBSERVATION } \\
\text { WELL }\end{array}$ & $\begin{array}{l}\text { PRODUCING } \\
\text { WELLS }\end{array}$ & $\underset{k h / \mu}{\text { nd-ft/cp }}$ & $\begin{array}{l}\text { ech } \\
\text { ft/psi }\end{array}$ \\
\hline H-6 & $\begin{array}{l}\text { Entlre } \\
\text { Melifield }\end{array}$ & $4.7 \times 10^{6}$ & $\theta$ \\
\hline$n-|0|$ & $\begin{array}{c}n-50,51,90 \\
91\end{array}$ & $1.5 \times 10^{6}$ & $2.3 \times 10^{-2}$ \\
\hline $\begin{array}{l}n-104 \\
n-10\end{array}$ & $\begin{array}{l}\text { M-53 Entire } \\
\text { Wellfield }\end{array}$ & Earthqu & $e^{3}$ \\
\hline $\begin{array}{l}\text { Two-rate } \\
\text { Tests }\end{array}$ & $\begin{array}{l}M-51 \\
k-90 \\
M-91\end{array}$ & \multicolumn{2}{|c|}{ Inhomogentetles } \\
\hline
\end{tabular}




\section{FINAL REMARKS}

The drilling activity at Cerro Prieto will continue at least at the present pace: six rigs will be operating in the field, about 20 new wells are scheduled to be completed in 1979.

As new wells become avallable two-rate flow tests and long-term interference tests have been planned to establish the characteristics of different blocks of the Cerro Prleto reservoir(s).

\section{REFERENCES}

1. "Proceedings Second United Nations Sympostum on the Development and Use of Geothermal Resources," San Franc1sco, Gallf., May 20-29, 1975, U.S. Gov. Printing of fice, 3 vols., 2466 p., 1976.

2. "Proceedings First Symposium on the Cerro Prieto Geothermal Field, Baja California, Mexico," San Diego, Calif., September 20-22, 1978, Lawrence Berkeley Laboratory, Rept. LBL-7098 (In preparation).

\section{ACKNOWLEDGMENTS}

Work partially performed under the auspices of the U.S. Department of Energy.

\section{GLOSSARY OF TERMS USED IN FIGURES 2 AND 3}

C.C.R.B. (Cople corto, rosca Buttress): Short connector, Buttress thread

C.C.R.R. (Cople corto, rosca redonda): Short connector, round thread

Cementada: Cemented

Colg. (Colgador): Hanger

Cond. (Conductor): Conductor casing

Cople Especial: Special connector

Cople Flotador: Floating collar

Cople Retén: Baffle connector

Cuñas Sencillas:- Simple wedges

Lastrabarrenas: Drill collars

Pérdida de Ciculación: Lost Circulation

Perf. (Perforactón): Wellbore

Pescado: Fish

Plano: Flat

Pozo: Well

Ranurada: Slotted

R.B. (Rosca Buttress): Buttress thread

R.H.S.E.U. (Rosca Hydrill Super EU): Super EU Hydrill thread

S.L.: Slotted liner

Tapón Cemento: Cement plug

Tapón de Fondo: Downhole plug

T.R. (Tubería): Casing

Tubo: Pipe 


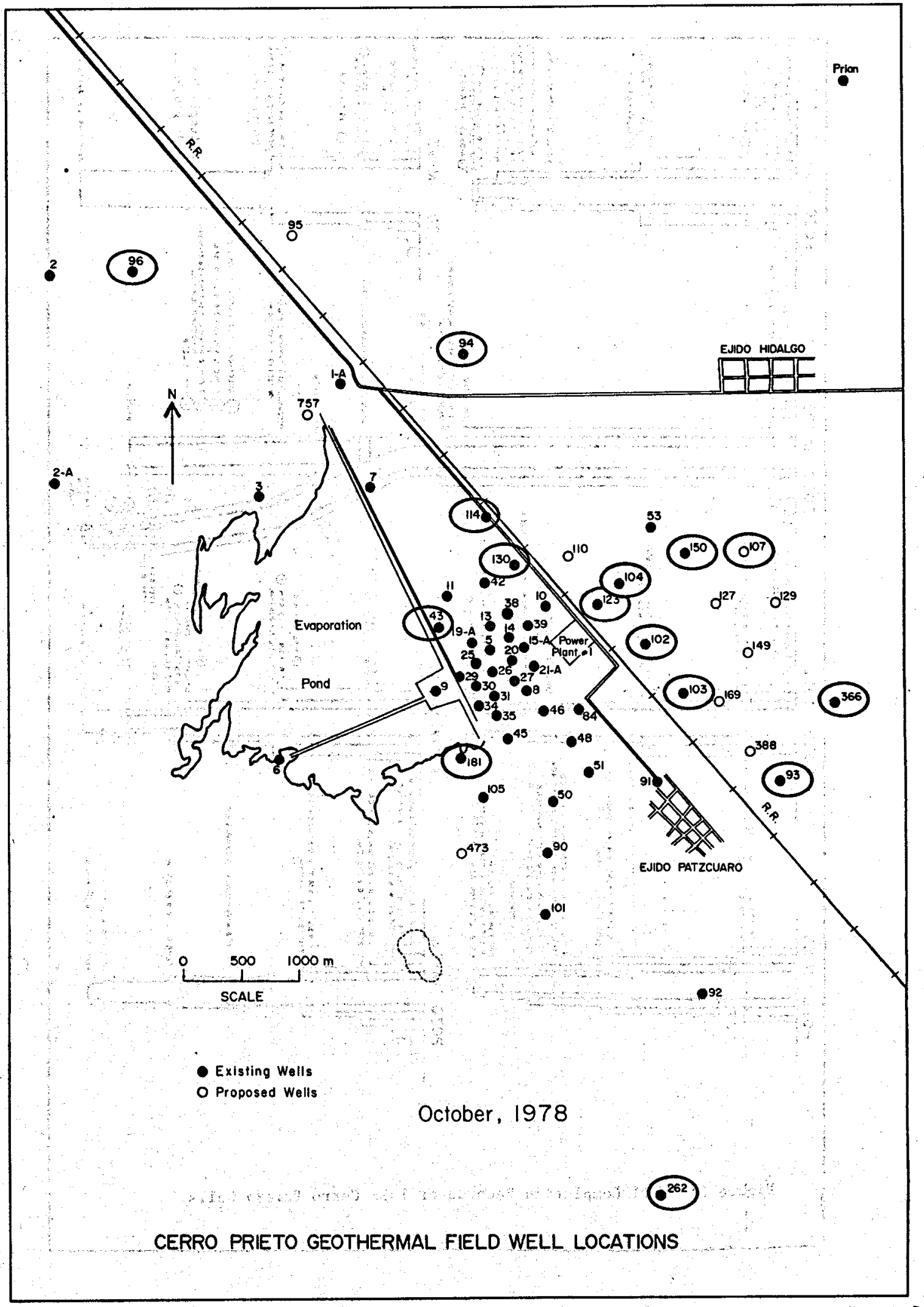

Figure 1: Location of 1978 Wells (Well numbers are circled). 


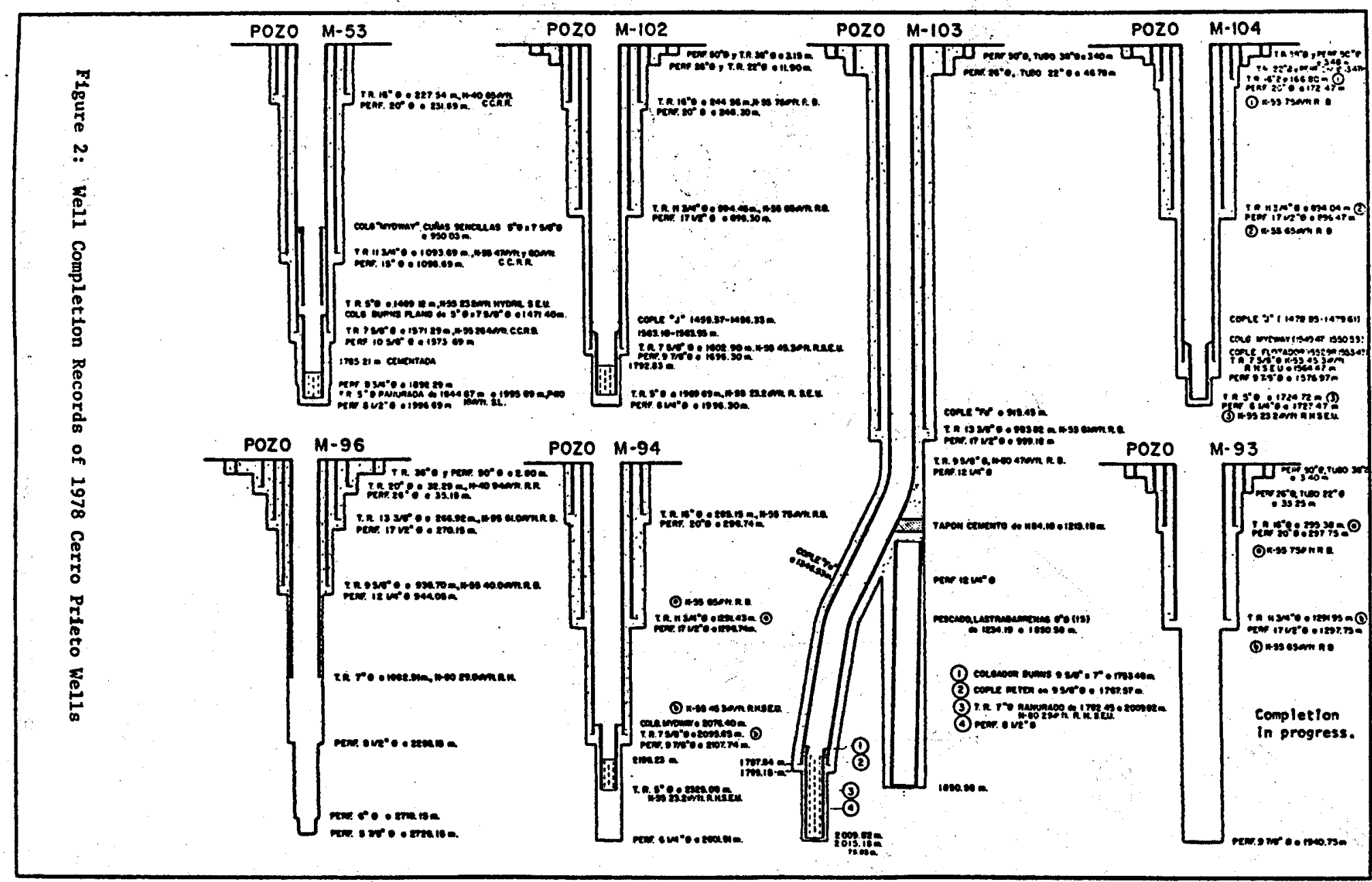




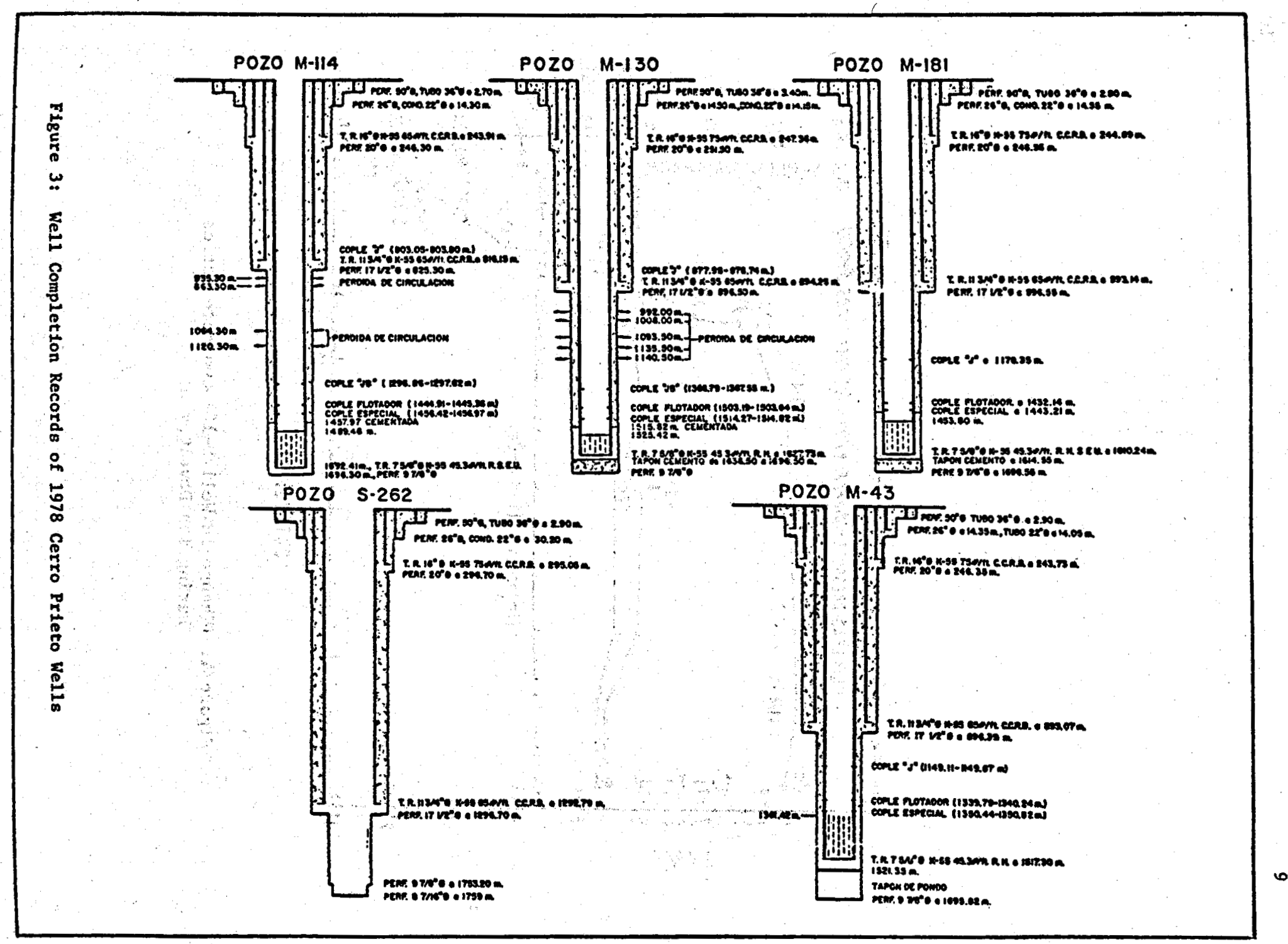




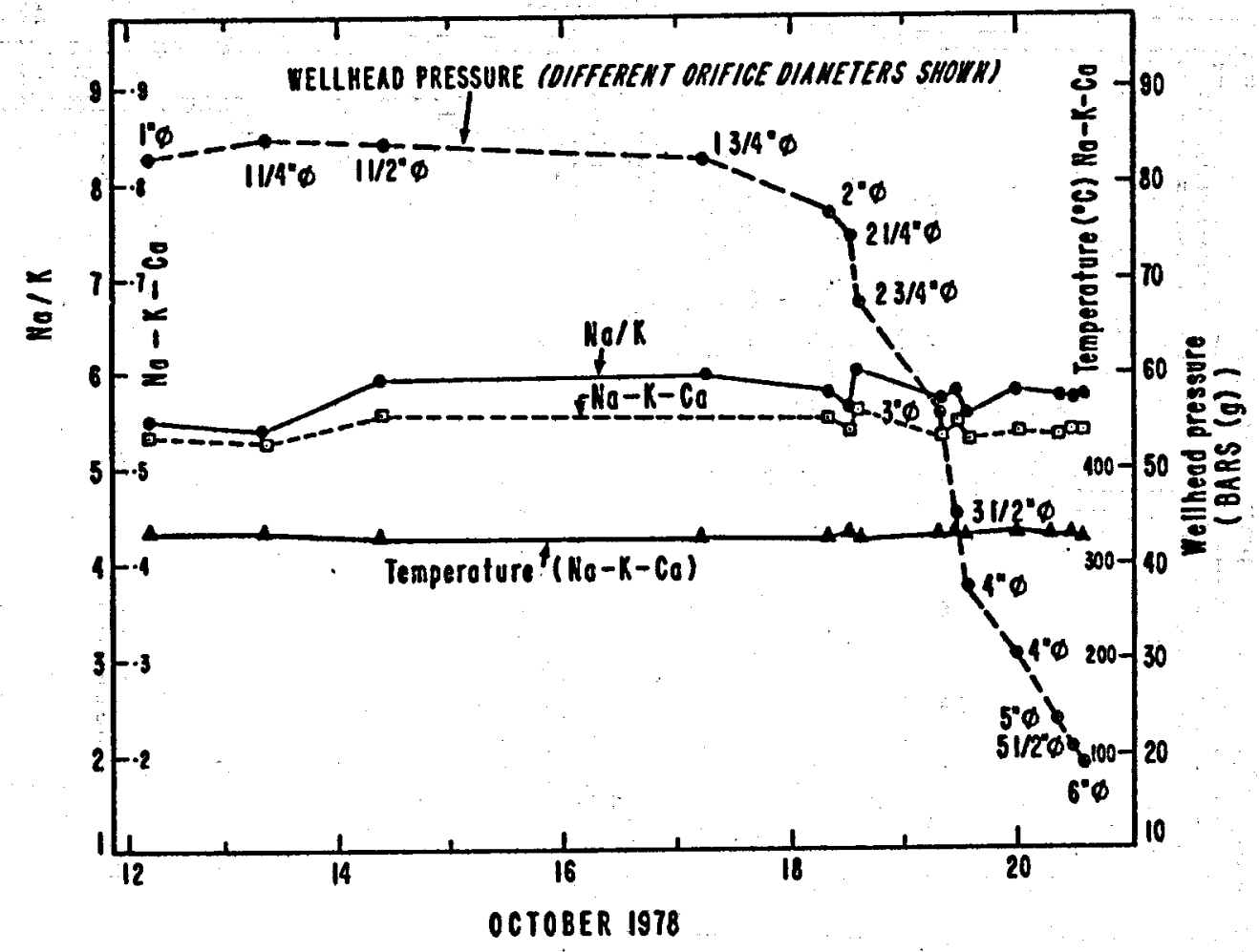

Figure 4: Change In We1l M-102 Characteristics During Its Development 